\title{
YOGYAKARTA URBAN MIDDLE-CLASS SUFISM: ECONOMIC, POLITICAL AND CULTURAL NETWORKS
}

\section{Yusdani ${ }^{1 a}$, Hujair AH. Sanaky ${ }^{1 b}$, Edi Safitri ${ }^{1 c}$, Imam Machali' $^{2}$, Muhammad Iqbal Juliansyahzen ${ }^{3}$}

${ }^{1}$ Universitas Islam Indonesia, ${ }^{2}$ Universitas Islam Negeri Sunan

Kalijaga, ${ }^{3}$ Institut Agama Islam Negeri Purwokerto

Email: ayusdani_msi@yahoo.com, bhujair.elhau@gmail.com, cedy_pasca@yahoo.com, 2imammachali79@gmail.com, 3iqbal.zen21@gmail.com

\begin{abstract}
The phenomenon of strengthening religious activity in the urban middle-class society in Yogyakarta Special Region in the last decade has been remarkable. The shift from the traditional Sufism to the model of piety associated with this middle-class Sufism further reinforce the middle class's religiosity. This study focused on the problem of the middle-class Muslim community when involving in Sufi practices. Through an in-depth interview with Sufi members and observation on their Sufi practice, this study shows that the urban middle-class Sufism pattern in Yogyakarta places emphasis on aesthetic-symbolic values. On the one hand, the tendency of religious patterns of Muslim communities is a form of negotiation between the values of spirituality in Islam and the forms and practices of global culture. On the other hand, the Sufi practice constitutes negotiation of the models of piety with economic-business motives. This Sufism is not institutionalized in conventional Sufism, commonly known as sufi order (tarekat) such as qadariyya, naqshabandiyya, and shattariyya, among the most popular Sufi order. Middle-class Sufism frames their distinctiveness in the form of economic, political, and cultural networks.
\end{abstract}

Keywords: Urban Sufi, Muslim Middle-Class, Spirituality

DOI: https://doi.org/10.20414/ujis.v23i2.342

\section{Introduction}

A RISING PHENOMENON of Islam in Indonesia lately is concerned with the emergence of a penchant for the mystical tradition and 
Islamic worship in the form of Sufism. The phenomenon of the rise of Sufism, especially among the urban middle-class population, seems to be a resistance to the flow of scripturalist Islamic modernism that was so hostile towards Sufism in the past century. Modern prominent urbanist reformers in organizations generally think that Sufism has encouraged violations of the core doctrine of the oneness of God through excessive praise of the teachers (shaykhs) in the congregation. Modernist Muslims consider that the emotional and mystical conditions invoked in Sufi practices are not characters that must be instilled by a modern Muslim.

However, in the $21^{\text {st }}$ century, Sufism has not disappeared from Muslims around the world. In contrast, Sufism is showing new strength in many places. Indonesia is one of the places where Sufism seem to have grown in the middle of the 20th century and now appears with a new passion in various forms, variants, and expressions. Sufism, in this context, has undergone intensive reexamination and changes in its features. The fact of a new passion in Sufism in Indonesia which is now rife in big cities and followed by middle-class people is sufficient evidence to show such a phenomenon. The infatuation of the middle class towards Sufism shows that Sufism these days has new forms. This phenomenon also shows that mysticism and related spiritual practices are enthusiastically in demand in the spiritual market in Indonesia.

Simple concepts that can be seen from the phenomenon of new urban middle-class Sufism are religious programs in various forms. It starts from courses and seminars with themes concerning spirituality, individual Islamic courses, Islamic television program, popular millennial Muslim preachers on the Internet, Youtube and social media. Through a unique spiritual development program that finally becomes a particular stamp, Asef finally promoted what he called "active piety". ${ }^{1}$ This is what Bayat later classifies as a new style of religiosity. Sufism which was previously in the private sphere, currently moves to the public sphere. ${ }^{2}$

1 Asef Bayat, Life as Politics: How Ordinary People Change the Middle East (Amsterdam: Amsterdam University Press, 2010).

2 Shinta Nurani, "Urban Sufism and Transformation of Islamic Culture In Millenial Society," Religia, October 2018, 158, doi:10.28918/religia.v21i2.1508. 
On the other hand, the development of middle Muslims in several countries is exciting to look at. Middle-class Muslims make a significant contribution to the development of countries in Asia such as Malaysia, ${ }^{3}$ India, ${ }^{4}$ Sri Lanka, ${ }^{5}$ and Iran $^{6}$. In Britain, "Islamic pop" music begins to develop and is influenced by the middleeastern middle class. ${ }^{7}$ The presence of middle-class Muslims saves the middle east. ${ }^{8}$ In the United States, the middle-class Muslim builds health organizations to advance their interests. ${ }^{9}$

In Indonesia, the symptoms of Sufism in the middle class have emerged since the 1980s. The emergence of the "new society layer" which is often referred to as the middle class is facilitated by the success of economic development and education transformation as a result of the New Order's moratorium program. Since the 1980s, the economic prosperity, and transformation of education results in Indonesia that has a large number of skilled workforces consisting of managers, trained workers, technicians, highly dedicated teachers, and lecturers, and other types of HR who are

${ }^{3}$ Wan Kamal Mujani et al., "The Political and Economic Contributions of the Muslim Middle Class in Malaysia," Advances in Natural and Applied Sciences 6, no. 3 Specl.Issue 2 (2012): 285-95; Daromir Rudnyckyj, "Subjects of Debt: Financial Subjectification and Collaborative Risk in Malaysian Islamic Finance," American Anthropologist 119, no. 2 (2017): 269-83, doi:10.1111/aman.12861.

${ }^{4}$ Anwar Alam, "Emergence of Muslim Middle Class in Post-Independence India and Its Political Orientations," Journal of Muslim Minority Affairs 35, no. 1 (2015): 123-40, doi:10.1080/13602004.2015.1007664.

5 Filippo Osella, “'A Poor Muslim Cannot Be a Good Muslim': Islam, Charitable Giving, and Market Logic in Sri Lanka," Religion and the Morality of the Market, no. May (2017): 217-39, doi:10.1017/9781316888704.011.

${ }^{6}$ Asemeh Ghasemi, "Muslim Iranian Women Working in Broadcast Media (IRIB): Between Motherhood and Professionalism," Women's Studies International Forum 53 (2015): 167-73, doi:10.1016/j.wsif.2015.01.003.

7 Carl Morris, "The Rise of a Muslim Middle Class in Britain: Ethnicity, Music and the Performance of Muslimness," Ethnicities, 2019, 1-21, doi:10.1177/1468796818822541.

8 Lawrence Rosen, "Will the Middle-Class Save the Middle East?," Contemporary Islam 5, no. 2 (2011): 186, doi:10.1007/s11562-011-0156-9.

${ }^{9}$ Lance D. Laird and Wendy Cadge, "Negotiating Ambivalence: The Social Power of Muslim Community-Based Health Organizations in America," Political and Legal Anthropology Review 33, no. 2 (2010): 225-44, doi:10.1111/j.15552934.2010.01112.x. 
quite qualified..$^{10}$ After the new order, Popular Islam became a new study to discuss. ${ }^{11}$

The transformation in education has a broad influence on the growing educated middle class that is ready to enter various types of employment. "With each of their professions, this educated middle class then became an important group in the government bureaucracy and also in many existing private sectors."12 In this context, many observers such as Hefner, ${ }^{13}$ Kuntowijoyo, ${ }^{14}$ Arief Budiman, ${ }^{15}$ and Ramage ${ }^{16}$ concluded that the new socio-economic class had emerged phenomenally in Indonesia as a middle class. In this middle class, there are several academics, intellectuals, reformers, intellectuals, young entrepreneurs, lawyers, political figures, cultural activists, technocrats, NGO activists, preachers, public figures, presenters, and economic observers. ${ }^{17}$ In a gender perspective, middle-class has allowed Muslim women to enter into the job market and professional workers. ${ }^{18}$

Interestingly, in Indonesia, the emergence of this class was also followed by an increased enthusiasm for religious and spiritual life. Vatikiotis testifies to this phenomenon: "In Indonesia, the revival of religious enthusiasm in the 1980s and 1990s was a typical middle-class phenomenon in urban areas - the segment of

${ }^{10}$ Valerie J Hoffman, Sufism, Mystic, and Saint in Modern Egypt (Columbia: University of South Carolina Press, 1995), 120.

${ }^{11}$ Farish A. Noor, "Popular Religiosity in Indonesia Today: The Next Step after 'Islam Kultural'?,' Al-Jami'ah 53, no. 2 (2015): 283-302, doi:10.14421/ajis.2015.532.283-302.

${ }^{12}$ Hamka, Tasawuf Modern (Jakarta: Pustaka Panjimas, 1993), 12-13.

${ }^{13}$ Robert W. Hefner, "Islam, State, and Civil Society: ICMI and the Struggle for the Indonesian Middle Class," Indonesia 56 (October 1993): 1, doi:10.2307/3351197; RW Hefner, "Islamization and Democratization in Indonesia," 1997.

${ }^{14}$ Kuntowijoyo, Paradigma Islam: Interpretasi Untuk Aksi (Bandung: Mizan, 1993).

15 Arief Budiman, Mencari Ideologi Alternatif: Polemik Agama Pascaideologi Menjelang Abad 21 (Bandung: Mizan, 1994).

${ }^{16}$ Douglas E. Ramage, Politics in Indonesia: Democracy, Islam and the Ideology of Tolerance. (United Kingdom: Routledge, 1995).

17 Azyumardi Azra, "Neo-Sufisme Dan Masa Depannya," in Religious Islam (Jakarta: Paramadina, 1993), 60.

${ }^{18}$ Ghasemi, “Muslim Iranian.” 
society most touched by economic development and social change. This phenomenon has a broad influence on the increasing religious adherence in Muslims who are enjoying prosperity as a middle class."19 Middle-class Muslims are voracious internet users. $^{20}$

A prominent feature that can be observed from the phenomenon of Sufism in the middle class in Indonesia, among others, is marked by the emergence of the phenomenon of Muslim women's clothing (veils/headscarves) since the early 1980s. When the use of veils/headscarves became popular, on the other hand, there was also a musical expression in the form of modern kasidah, which became a symbol of the religious and spiritual thirst of the urban-educated people. The arid soul of this urban Muslim community is doused by the coolness of modern kasidah music in the form of pop music displayed by Bimbo or similar artists - in the era of the 1980s. In most contemporary time, Nisa Sabyan represents a model of musical instruments for Muslim middleclass. ${ }^{21}$ The increasing label of "halal" food ${ }^{22}$ and the marketing of godly behaviour through charity work ${ }^{23}$ are blatant examples of the development of a middle Muslim society.

Those features clearly show the shifts and modes of piety associated with Sufism. The choice of media and the taken new types of communication clearly shows the new articulation of Sufism in Indonesia. The main hypothesis developed in this study is that there has been a shift and reinterpretation of the meaning of Sufism, which not only revolves around the esoteric tradition but

19 Abdul Qodir Djaelani, Koreksi terhadap Ajaran Tasawuf (Jakarta: Gema Insani Press, 1996), 152-53.

20 Yuswohady and Kemal E. Gani, 8 Wajah Kelas Menengah (Jakarta: Gramedia, 2015).

${ }^{21}$ Makrifatul Illah, “Pesan Dakwah Lagu 'Deen Assalam'; dipopulerkan group gambus Sabyan" (UIN Sunan Ampel Surabaya, 2019).

22 Akhmad Mahbubi, Tomohiro Uchiyama, and Katsumori Hatanaka, "Capturing Consumer Value and Clustering Customer Preferences in the Indonesian Halal Beef Market," Meat Science 156, no. April (2019): 23-32, doi:10.1016/j.meatsci.2019.05.012.

${ }^{23}$ Hilman Latief, "Marketizing Piety through Charitable Work: Islamic Charities and the Islamization of Middle-Class Families in Indonesia," no. May (2017): 196-216. 
also relates to the modern world. Further, at specific points, the media, da'wa (Islamic sermon and propagation), and spiritual matters become intertwined in the world of contemporary Sufism.

The research problem discussed in this study is concerned with the problem of the urban middle-class community's infatuation in following Sufism practices. The research site was focused on various activities of dhikr (recitation and remembrance of God) in Yogyakarta, such as the one under the guide of famous rising young Muslim preacher and entrepreneur Yusuf Mansur. The phenomenon of urban Sufism can be observed from the rampant routine recitations held in hotels, which are followed by entrepreneurs, academics, activists and officials. An example of this was a massive gathering of dhikr in Yogyakarta Wanitatama building in 2016 .

The phenomenon of strengthening religious activities in the urban middle class is very interesting to study. On the one hand, the strengthening of religious activities is undoubtedly very positive and needs to be supported by all parties. This is because these activities have influenced their religious awareness"becoming more religious" at the level of worship, but on the other hand, the strengthening of these activities also shows a tendency that leads to what is known as "religious exclusivism. "

\section{Urban Sufism and New Religiosity Model}

Sufism is an earnest effort by isolating oneself while contemplating, detachment from everything worldly and focusing only on God so that someone can unite with Him. ${ }^{24}$ According to al-Junaidi al-Bagdadi, Sufism is the cleansing of the heart from the nature that is equal to animals, emphasizing the nature of humanity (bashariyya), avoiding lust, giving place to spirituality, holding on to the science of truth, practising something more primary on the basis of eternity, giving advice to the people, genuinely keep their promises to Allah and follow the Shari'a of the Messenger of Allah. ${ }^{25}$

${ }^{24}$ Djaelani, Koreksi terhadap Ajaran Tasawuf.

${ }^{25}$ K Permadi, Pengantar Ilmu Tasawuf (Jakarta: Rineka Cipta, 1997), 28-29. 
Sufism or tasawuf is seen as an embodiment of the basic teachings of Islam, namely Faith, Islam, and Ihsan which aim to worship God with full awareness, that human beings are near Him so that every slightest human movement is in His observation. Harun Nasution explained that Sufism aims to get a direct relationship with God and is fully aware that the relationship is from God because the essence of Sufism is the awareness of communication and dialogue between the spirit of man and God by seclusion in contemplation. ${ }^{26}$

The contents of the study of Sufism can be classified into three types, namely Akhlāqī Sufism, 'Amalī Sufism, and Falsafì Sufism. Akhlāqi Sufism prioritizes moral progress rather than human dignity. To achieve this, an individual must pass three stages, namely takhalli (rid of the despicable qualities of birth and mind), tahalli (adorn oneself with praiseworthy qualities), and tajalli (loss of the hijab (spiritual barrier). Amali Sufism emphasizes the physical aspect (Shari'a) to achieve spiritual perfection. There are four ways in this kind, namely sharia, țarīqah, haqīqah, and ma'rifah. Meanwhile, Falsafi Sufism is Sufism whose teachings combine mystical vision with a rational vision and the disclosure of its teachings using philosophical terminology. The terms used in Sufism are fan $\bar{a}^{\prime}$ and baqa (merging), ittihad (unifying), hulūl (unification), wahdah al-wujūd (unity of being), and ishrāq (shining).

This study analyzes the phenomena of urban middle-class Sufism from three perspectives. Asep Bayat's perspective of new religiosity models, which is "active piety" is the first model. ${ }^{27}$ The concept of active piety sees how individuals construct themselves to show their level of spirituality. This concept is more appropriate to be used to observe the phenomena of the practices and spiritual programs that emphasize ritualism, and primarily through the media and groups of worshipers. In Indonesia, the forms of active piety are indeed more promoted by new styles of lecturing and the revival of remembrance, which is shown on television. In addition,

26 Harun Nasution, Falsafah dan Mistisisme dalam Islam (Jakarta: Bulan Bintang, 1973), 56.

${ }^{27}$ Bayat, Life as Politics: How Ordinary People Change the Middle East. 
the activities are displayed through forums such as tasawwuf courses and Islamic studies guided by scholars and clerics.

This study also analyzes the phenomenon of urban middle-class Sufism from the media perspective to see how the media plays a vital role in promoting the new style of spiritual development programs, which are guided by clerics, preachers or scholars. Here is also essential to see whether the media is genuinely neutral in presenting the program or, like most business institutions, the interests of the media are more critical. Patrick Haenni calls the growing demand on Islam represents "Islamic market" ${ }^{28}$ This is a relevant concept since teachers and clerics often use media for their spiritual programs and to catch the market of Islamic spiritualism.

Abraham Maslow's theory of hierarchy is the other helpful perspective. ${ }^{29}$ The priority is physiological needs such as eating and warmth. If these needs are met, then the next one is the need for safety, then the social needs, and when those have been fulfilled, comes the need to be respected. When the needs are again met, then intellectual needs become further needs, followed by the next need, which is aesthetic needs, namely beauty and neatness. The last need is the need for self-actualization, namely, to find one's persona; identity and achieve self-potential. ${ }^{30}$

\section{The Communication of Middle-Class Muslim Sufism in Yogyakarta}

Sufism in the urban middle-class Muslim community in Yogyakarta changes the dimensions of asceticism (tapa brata) of conventional Sufism. This is almost the same as the Protestant

\footnotetext{
${ }^{28}$ Patrick Haenni, Market Islam, the Other Conservative Revolution (Paris: Seuil, 2005).

${ }^{29}$ A. H. Maslow, "A Theory of Human Motivation," Psychological Review 50, no. 4 (July 1943): 370-96, doi:10.1037/h0054346.

30 Jarvis Matt, Teori-teori Psikologi; Pendekatan Modern untuk Memahami Perilaku, Perasaan dan Pikiran Manusia (Bandung: Nusa Media, 2000), 95.
} 
ethics which encourage the attitude of hard work, saving, sharing, and living only as a way to reach happiness in the hereafter. ${ }^{31}$ This motivation can be found amongst the companions, who state that even the Prophet himself becomes an intermediary to enter heaven.

The communication built by the middle-class Muslims uses several variants. Usually, this communication model can be seen with the emergence of televangelical Islamic preaching led by popular clerics such as Ustadz Maulana, AA Gym, and Mamah Dedeh. In the scope of the Yogyakarta City, the same model is usually held by Nurul Asri Mosque. The other forms include memorizing and reciting the Qur'an, such as communities of "one day one juz" (reciting one surah of the Qur'an every day, abbreviated as ODOJ), or forums of Islamic teaching, such as liqa ${ }^{\prime}$ and refining the correct reading ( $t a h \sin )$ of the Qur'an.

Other communications include charity activities. The charity model is conducted in various ways. Those who share the same vision will instinctively be called to participate in similar activities. This is due to the similarity of ideas and goals in the meaning of religion in social space, with other terms. This is also called the cooperative movement for charity. "Waroeng Steak and Shake", for example, applies the concept of charity in its business activities. Also, employees who work in the business are required to take part in religious activities, such as morning prayer $(D u h \bar{a})$ and memorizing accessible chapters of the Qur'an. For the business owner, it is a way to do business based on the concept of Islam. The business owner calls it spiritual company. Spiritual Company (SC) is an idea initiated by business owners in applying sharia principles in their companies. This is regardless of whether the final goal is to develop the economy through Islamic means or vice versa. The SC system applies the principles starting from the employees to display sharia-nuanced invitations to customers. The SC system is actually habituation in the practice of religious teachings. According to the business owner, preaching directly

${ }^{31}$ Wasisto Raharjo Jati, “Less Cash Society: Menakar Mode Konsumerisme Baru Kelas Menengah Indonesia," Jurnal Sosioteknologi 14, no. 2 (August 2015): 102-12, doi:10.5614/sostek.itbj.2015.14.2.1. 
through the system was more comfortable for the employees than to preachers.

Another model of charity that is quite interesting to see as a communication model of middle-class Muslim is the Sedekah Group model (SR). This model brings together donors through websites and campaigns on social media and the masses. This movement was driven by Saptoari. He is also active in the world of shariabased business (Tengkleng Hohah), and also as a motivator, writer and preacher. Through his movement, he succeeded in gathering many donors and channelling them to sharing recipients. With the slogan "Looking for Face in Front of God", this movement succeeded in gathering communal movements in the Middle-class Muslim community who wanted to devote their wealth but were confused in the way of channelling it. SR prioritizes to the following alms recipients such as disabled children's orphans, abandoned baby orphans, orphans, poor old widows, ill-poor people and needy students. Donations are also given to building Islamic boarding schools, mosques and worship equipment (sarong, female Islamic dress of mukena, and the Qur'an).

Other activities carried out by the middle-class Muslim communities in Yogyakarta include a routine Qur'an recitations held, for example, by Waroeng Group. Every week or every month, they hold recitation activities that bring together entrepreneurs and the surrounding community in a mosque. Free medical treatment and blood donors are also offered in the sideline of this religious activity.

\section{Patterns and Forms of Middle-Class Muslim Sufism}

Amid the spirit of discovering identity, the urban middle-class Muslim community attempt to find lost spiritual values. From here then comes the urban Sufi phenomenon or what is often called urban Sufism. This phenomenon is something that happens in almost all major cities in the world. In simple terms, Howell defines urban Sufism as the birth of passion spirituality (Sufism) of the urban Muslim community in Indonesia. Howell saw this emerging spirituality passion represented by middle-class Muslim societies with Neo-modernist backgrounds. Although in subsequent developments, she realized that the phenomenon of 
passion for spirituality did not only appear in the urban middleclass Muslim community with a modernist background. However, it also comes from the congregation, which is followed by urban middle-class Muslims from the ideological line of the traditionalists. This appealed to Howell, where Neo-modernists who were biological children of previous modernism, rejected the doctrine of Sufism without reserve. Genealogically, the term urban Sufism is a continuation of Neo-Sufism. This Neo-Sufism movement was a criticism of the Sufism (classical) tradition with key figures such as Abū Hiāmid al-Ghazzālī, Suhrawardī alMaqtul, and al-Qushayri. The Neo-Sufism movement wants to reject the traditional Sufi teachings, especially those that relate to wahdah al-wujūd, ittihad, hulūl, and wahdah al-adyān. ${ }^{32}$

Martin argues that the birth of Sufism in several major cities in Indonesia is predicted to emerge in the early 1980s when urban Muslim middle classes began to form. With an excellent educational background, the city's Muslim community has a career in various sectors both in the government and domestic sectors. ${ }^{33}$

A different view was put forward by Louis Massignon. The assumption is that Sufism will not survive in the modern era. He argued that the mid-20 $0^{\text {th }}$-century congregation had been paralyzed because of continuous attacks from the modern Muslim elite. This constellation is also reinforced by the assumption that spiritualism, which is the core of Sufism and congregation is not compatible with modernity, which continues to increase its momentum in almost all Muslim countries since the $18^{\text {th }}$ century. Western scholars presume that religion will be replaced by science, and the functions of religion will decrease in human life.

What is happening now is simply the opposite of such an assumption. Amid the pressure of materialism glorified by modernism, Sufism can survive and adapt to the development. Conventional Sufi practices can blend with modernity. The

32 Martin van. Bruinessen and Julia Day Howell, Sufism and the "Modern" in Islam (I.B. Tauris, 2013).

${ }^{33}$ Din Wahid, "Sufism and the 'Modern' in Islam," Studia Islamika 10, no. 3 (March 2014), doi:10.15408/sdi.v10i3.628. 
emergence of high interest in the spiritual path has lately become an interesting phenomenon in the lives of urban communities in Indonesia. ${ }^{34}$ The spiritual path becomes the answer of modern humans when they face their essential emptiness. The existence of life in its modern spiritual problem amid urban dynamics is answered by the existence of this spiritual path.

Initially, this Sufi movement developed in the rural area. However, then this Sufism developed in the direction of the urban area. Urban people who are trapped in the cosmopolitan life with electrical material need refined touches in their lives. Remembrance (dhikr) activities commonly carried out by Sufism groups are the answer to the spiritual aridity.

Significant economic development in Indonesia, especially in the post-new order, has increased the number of middle classes in urban areas. This certainly also makes the number of Muslim urban communities continue to increase. The Urban Muslim community is one of the new classes in the social class structure in Indonesia. They are a rationally educated society. It becomes an interesting phenomenon when the community comes into contact with Sufi values and practice that in some ways, tend to be irrational.

The power of remembrance of prayer and other spiritual touches is a delightful treat for urban communities. Remembrance is one of the most important teachings in Islam, which also gets emphasis in both the Qur'an and hadith. In the tradition of Sufism, remembrance is even at the core of all teachings conveyed by a murshid (Sufi teacher). Sufi teachers generally create specific formulas for remembrance that distinguishes one group from another group of Sufi order. However, this will later form an exciting thing in the world of Sufism when the conventional values of Sufism that develop in the rural encounter the urban middle-class Muslims.

${ }^{34}$ Muhrison M. Nuh, Aliran/Faham Keagamaan dan Sufisme Perkotaan (Jakarta: Departemen Agama RI, Badan Litbang dan Diklat, Puslitbang Kehidupan Keagamaan, 2009), 17. 


\section{Middle-Class Muslims and Urban Sufism}

Discussion of the middle class is not novel. However, studies on Sufi practice in the urban environment is a recent trend. The urban Muslim community in Indonesia emerged after 1998, which had previously been marked by the emergence of various kinds of Islamic products such as the Republika newspaper, Bank Muamalat, and other types of Islamic products. The appearance of this post-1998 middle class Muslim shows the ideals and image of the middle class that are adaptive to the state. Islam becomes an identity that can be negotiated with the state while still maintaining their Muslim identity. ${ }^{35}$

Wasisto notes that the emergence of urban Sufism among Muslim middle class in the urban area can be analyzed in two essential premises. First, the phenomenon showed that both intensity and actuality of piety as a solution to modern life problems. Second, urban Sufism has become the collective identity of the Muslim middle class to distinguish it from other types of the middle class. Those conditions then implicated toward the emergence of popular culture in order to strengthen Sufi as piety path. ${ }^{36}$ Urban Sufism is a socialreligious phenomenon of urban society arising from the quest on the spiritual dimension of religion. One significant factor that encourages this movement is the missing aspect of spirituality among the urban people..$^{37}$

This Middle-Class Muslim is a massive force in the process of nation-building. There are at least four reasons why the middle

35 Wasisto Raharjo Jati, “Tinjauan Perspektif Intelegensia Muslim terhadap Genealogi Kelas Menengah Muslim di Indonesia," ISLAMICA: Jurnal Studi Keislaman 9, no. 1 (September 2015): 1, doi:10.15642/islamica.2014.9.1.1-29.

36 Wasisto Raharjo Jati, "Sufisme Urban di Perkotaan: Kontruksi Keimanan Baru Kelas Menengah Muslim," Jurnal Kajian dan Pengembangan Manajemen Dakwah 05, no. 2 (2015).

37 Farid Mustofa, "Urban Sufism: The New Spirituality of Urban Communities in Indonesia," Jurnal Filsafat 22, no. 3 (December 2012): 218-26, doi:10.22146/jf.3096. 
class can be a very significant force. First, it seems that the middle class has very close relations with democracy. If democracy has a cross causal relationship with growth, it can be concluded that the middle class also causes growth. The second is because the middle class provides entrepreneurship that creates jobs so that productivity in the community can grow. Third, the accumulated value of human capital owned by the middle class is significant for economic growth. The fourth, middle classes can drive highquality goods consumer demand. This can increase the scale of production because they have the willingness and ability to pay extra for these high-quality products. This certainly can encourage a more dynamic process of economic activity so that economic growth can increase..$^{38}$

In the context of the urban Muslim community, the strength of Islam becomes one inseparable variable. Islam is a potential force because it has a strong social basis. About $87.2 \%$ of the total population of Indonesia profess Islam. Specifically, the Asian Development Bank makes the middle-class expenditure categorization into three groups. First is the lower middle class, with USD 2-4 per day. Second is the middle-middle class, with USD 4-10 per day. The third is the upper-middle class, with USD 10-12 per day. The main striking element from the emergence of middle-class consumption behaviour is a direction to improve the quality of life and fulfilment of social needs. ${ }^{39}$

Urban Sufism develops due to various factors. The factors that lead to the development of Sufism in urban areas are as follows. First, Sufism is a means of searching for the meaning of life. An urban Muslim community that lives in a cosmopolitan spark that is full of material interests requires a real-life goal. The competitiveness and self-centred life of the urban community is the reason for the urban Muslim community to seek the true meaning of their life.

38 Muhammad Afdi Nizar, “Kelas Menengah (Middle Class) dan Implikasinya bagi Perekonomian Indonesia," Bunga Rampai Ekonomi Keuangan, no. June (2015): 173-91.

${ }^{39}$ Jati, "Sufisme Urban." 
Second, Sufism is a means of intellectual struggle and enlightenment. In the Sufi world, one of the sources of strength that makes it possible to survive until now is the authority of the scientific chain or the pedigree of Sufi master (murshid). Third, Sufism can be a means of psychological therapy. Urban Muslim communities that live during a cosmopolitan era need a psychological approach to calm their souls. In very crowded work and various interests that are mutually pressing, the urban Muslim community wants to gain new enlightenment in their lives.

Fourth, Sufism can be a means of strengthening religious traditions. In the Indonesian context, the issue that developed since the beginning of the Islamization process was Sufism. In every region where Islam develops, both at the level of the kingdom and society, Sufism always colours the picture that appears. This is in line with what was stated by A. H. Johns. ${ }^{40} \mathrm{He}$ explained that the most influential in the process of Islamization in the archipelago were Sufi teachers.

Fifth, the liberal market economic system creates a large gap or a line of demarcation between the poor and rich people. As released by the Central Bureau of Statistics (BPS) as of March 2016, the coefficient of Gini ratio (a measure of the degree of inequality in population distribution) of Indonesian people reached 0. $40 .{ }^{41}$ This figure is still quite far compared to other ASEAN countries.

Besides, the practices in the liberal economy that are applied in Indonesia seems contradictive with the rules of religion that exist in Islam. An example is concerned with the banking system and practice. Although it is still debatable due to interest in bank practices, some urban Muslim communities view that the practice of bank interest is a part of usury (ribā) which is prohibited in Islamic law.

Based on this view, the urban Muslim community builds economic associations which is designed to be a sharia-compliance banking system. The network aims to improve the welfare of the

40 Anthony H. Johns, "Sufism as a Category in Indonesian Literature and History," Journal of Southeast Asian History 2, no. 2 (1961): 10-23.

41 Admin, "Badan Pusat Statistik," accessed September 13, 2019, https:/www.bps.go.id/pressrelease/2018/07/16/1533/gini-ratio-maret-2018tercatat-sebesar-0-389.html. 
community in line with Islamic religious value and teaching without having to clash with usury. The movement against usury is based on religious-spiritual spirit. The common interest in building an Islamic economic system is the basis of enthusiasm in building an economical chain network.

\section{Patterns and Forms of Urban Sufi}

In various literature, these patterns and forms of movement from urban Sufis are complicated to distinguish. In general, however, the pattern of urban Sufis can be mapped into two models. The first is the Sufism movement which still adheres to the conventional congregation organization system. The second is the ones who developed Sufism without being bound to specific congregation organizations.

Based on the Sufi movement pattern, the form of urban Sufi can be grouped into four forms, namely, first in the form of an institutionalized urban Sufi movement. What is meant by this group is that spiritual activities that are carried out through teaching activities and exciting spiritual courses. Spiritual training is packaged in training activities that are not boring. The material delivered is related to Sufism. Through the organized teaching and training activities, Sufism is packaged in an attractive form to fulfil the desire of urban Muslim communities who are thirsty for spiritual values. It can also take other forms, such as Tazkian by Jalalluddin Rahmat. This institution tries to introduce Sufism to urban communities in the form of short courses and provide a remembrance guide. ${ }^{42}$ The participants are elite people such as government officials, high-ranking military officers, and wealthy people in the business. Another example is The Indonesia Islamic Media Network (IIMAN) established by Haidar Bagir. Within the institution, there are training classes, workshops, and spiritual coaching with a reasonable income. ${ }^{43}$ Other examples are like

42 Mohammad Misbah, "Fenomena Urban Spiritualitas Solusi atas Kegersangan Spiritual Masyarakat Kota," KOMUNIKA: Jurnal Dakwah dan Komunikasi 5, no. 1 (November 2016): 135-46, doi:10.24090/komunika.v5i1.776.

43 Julia Day Howell, "Sufism and the Indonesian Islamic Revival," The Journal of Asian Studies 60, no. 3 (August 2001): 701-29, doi:10.2307/2700107. 
Nurul Mustafa Group, ${ }^{44}$ Majelis Shalawat Muhammad,45 Kelompok Kesenian Sufi Multikultural, ${ }^{46}$ and Tari Sufi Al Fairouz. ${ }^{47}$

This is certainly different from the remembrance formulation taught by conventional Sufism groups. Remembrance and prayer taught by conventional Sufism groups are often a combination of what is taught by the Prophet Muhammad and the Salaf scholars with the formulation of remembrance resulting from the self "concoction" which is generally in the local language (Indonesia). In another form, One Day One Juz (ODOJ) is an example of a movement based on social media. ${ }^{48}$

Meanwhile, in the urban Sufism movement group, the teaching of remembrance is loose and not bound by the standard and specific congregation. Besides, in participating in the remembrance activities and prayers, pilgrims do not have to go through bay'at (oath of allegiance), like in traditional Sufi order. Besides, the method of remembrance is quickly followed by laypeople because it is translated into Indonesian.

The third is the conventional congregation organization itself. Examples of these include Khalwatiyya, Naqshbandiyya, Naqshbandiyya-Qadiriyya, Tijaniyya, and other congregations. In the congregation movement, it is divided into two categories on the basis of acknowledgement, namely mu'tabarah (admitted and well-known) and ghayru mu'tabarah (less known). If it is not included in the two categories of Sufism, then it is only morality

${ }^{44}$ Arif Zamhari, "Socio-Structural Innovations in Indonesia's Urban Sufism: The Case Study of the Majelis Dzikir and Shalawat Nurul Mustafa," Journal of Indonesian Islam 7, no. 1 (2013): 119-44, doi:10.15642/JIIS.2013.7.1.119-144.

${ }^{45}$ Rubaidi Rubaidi, "The Role of Urban Sufism of Shalawat Muhammad Assembly on Urban Middle Class Society," Jurnal Ushuluddin 26, no. 2 (2018): 183, doi:10.24014/jush.v26i2.4895.

${ }^{46}$ Dadang Dwi Septiyan and Rista Dewi Opsanti, “Dimensi Mistik Musik Sufi Kelompok Kesenian Sufi Multikultural Kota Pekalongan," Jurnal Pendidikan dan Kajian Seni 3, no. 1 (April 2018), doi:10.30870/jpks.v3i1.4067.

${ }^{47}$ Mega Nurvinta, "Eksistensi Tari Sufi pada Komunitas al-Fairouz di Kota Medan," Gesture: Jurnal Seni Tari 5, no. 1 (April 2016): 85-98, doi:10.24114/senitari.v5i1.3605.

${ }^{48}$ Eva F. Nisa, "Social Media and the Birth of an Islamic Social Movement: ODOJ (One Day One Juz) in Contemporary Indonesia," Indonesia and the Malay World 46, no. 134 (2018): 24-43, doi:10.1080/13639811.2017.1416758. 
precept. Mu'tabarah congregation is believed to a have a robust genealogical link of Sufi masters and their teacher that end up upward up to the Prophet Muhammad.

Meanwhile, ghayru mu'tabarah is a congregation which facilitates (does not continue) its sanad to the prophet Muhammad (pbuh). This division aims to avoid the deviation of Sufism from the straight lines that have been laid by earlier Sufis. With this division, the scientific sanad line is maintained. This congregation initially appeared in urban areas and shifted to the rural ones. However, lately, it again appears in urban areas.

The fourth is an urban Sufism that teaches spirituality eclectically. In its training, it is clear that eclectic nature can be seen with a spiritual training model that is not bound by specific religious barriers and affiliations. For example, as was done by Anand Krishna. He presented various kinds of religious characteristics which were combined into the "ala Anand" spiritual menu. In training, it seems that he wanted to take advantage of the economic potential of all the religions developed in the community. Another example is Salamullah group established by Lia Aminudin (Lia Eden), the female reader who claimed herself a prophet.

\section{Yogyakarta Urban Middle-Class Muslim Sufism Network}

\section{Economic Network}

The rise of the middle class is indirectly proportional to the increasing demand for lifestyle products, beauty products and health. It also increases the demands on the tourism and transportation sectors, which will also have an impact on various premium-class products, including high-end properties. This phenomenon eventually grew a new theme in the 2010 marketing strategy with the approach of youth, women, and netizen segment. This growth will automatically have an impact on better purchasing power, especially in the trade sector and premium class quality, including upscale property. ${ }^{49}$

${ }^{49}$ Rofhani, “Pola Religiositas Muslim Kelas Menengah di Perkotaan," Religió: Jurnal Studi Agama-agama 3, no. 1 (March 2013). 
The above explanation clearly shows that Sufi urban development cannot be separated from economic networks. The rise of the middle class that loves the Sufi spiritual path like what is happening today, including in Yogyakarta, has implications for the economy; increasing demand for products in various sectors: products in the category of lifestyle, health, tourism and transportation sectors. These all create an economic network based on religious identity.

Related to the economic impact of the strengthening urban Sufi phenomenon in Yogyakarta, it shows the link between products and market by the strengthening of religious identity in Yogyakarta. The products, therefore, are also adapted and inspired by a preferred religious identity. For example, among them are related to sharia-based clothing products and so on. Also, reading books about morality, mysticism, spirituality, and Sufism are widely circulating.

Student groups play an essential role in raising urban Sufi issues through on-campus discussions, which eventually boost sales of Sufi books. Then, the model, design, style, business practices and sales of sharia-based goods continue to be popular. We quickly find Muslim fashion outlets, Islamic banks, high-cost Islamic identity schools, Islamic-themed soap opera shows, sharia salons, sharia pawnshops, sharia tours, and sharia-labelled hotels. Primordialism-based business networks or religious sentiments (sharia) appeared when the Muslim movement of what is called "212" was upset to a bakery factory that did not support. In response, the supporters shouted a boycott of the factory product that caused a decline in sale for several weeks.

It is also added that Muslims need to fill the empty sector. Let us enliven our commerce by raising profiles of pious people. So that good asset is managed by good people and distributed to good people. Because Muslims do not care about this, as they are only busy with one dimension, then others take over this.

However, it should also be noted that the phenomenon of the diversity of middle-class Muslims in doing business and using the sharia label may make Islamic values as the basis for inspiring Islamic attitudes and behaviour or only formalistic and utilizing religious symbols for commercial purposes. In other words, Islam 
(Islamic sentiment) is used as a market booster, not merely as a spiritual awakening as described above. This means that this is a business problem and how to read opportunities and strategies to attract Muslims as a strategic market that has nothing to do with religious spirituality.

It is undeniable that the proliferation of various products with religious identity has motivated Yogyakarta's middle-class Muslims. This strategy is considered valid, especially since the Muslim communities in Indonesia tend to be less aware of the use of religion to boost business. Existing data shows that the majority of the respondents support and consider this to be reasonable and even something positive and supported. Further, the proliferation of businesses in various sectors by using the sharia appendages from slaughterhouses to properties developed in Yogyakarta shows not only the sensitive issues of religion but also the rise of religious preaching. Such economic movements are part of the communication and networks of the Yogyakarta urban Muslim class that can attach and evoke a primordial spirit between them.

\section{Political Network}

The political approach as a basis for communication and networking seems to be observed today even though in different contexts and problems. As stated by Iwan, who tried to make the involvement of the Qur'an, hadith, the stories of the Salaf al-sālih (pious companions and first generations) and the leaders of the national movement as suggestions. He illustrates:

"It is called așhāb al-kahfi. Seven young people lived in a damaged country. The system was damaged, the king was a despot, but they did not stay silent. They were sure that there would be no chance to stay in the system again. The choice, if they remained, was that they would be killed by the system even though their idealism did not want to enter the system. Finally, they opted out. They existed not because they wanted to go out of the system, but they wanted to improve the system."

Furthermore, Irwan also added that in the early 20th century, new figures emerged in the Indonesian movement. In the past centuries, there was Prince Diponegoro and before there had been Prince Mangkubumi, of which he struggled to raise weapons against invaders. Amazingly, the Dutch had learned from 
Andalusia on how to defeat Muslims. How did they defeat Islam? They created internal conflict. At the end of the 20th century, his struggle was replaced, no longer taking up arms. HOS Cokroaminoto with his friends gathered as they entered the new world. They chose the trading path. It was not the traders but the scholars who trade. So, Islam entered Indonesia through the trade route. The economic motive in the mindset of a warrior was toward freedom of his country from foreign occupation. What had been done by HOS Cokroaminoto was effective.

Iwan's statement above found its justification if it was associated with a demonstration movement of some Muslims in Monas demanding that Basuki Cahaya Purnama (Ahok) be charged for blasphemy and later shifting to the political movement. Initially, the movements of 411 and 212 demanded that Ahok be jailed, but later the boundaries became blurred between pure social movements and political movements. When this movement managed to drag Ahok to the prison, this movement did not stop - but continuing to consolidate the reunion of the movement seeking to bring about ukhuwwah Islämiyyah (as a form of Islamic Nationalism) which requires Muslims to unite as a political movement for contestation in the 2019 Election.

In general, it can be presumed that the act of defending Islam (aksi bela Islam) I, II and III were more coloured by urban Muslim groups-including the urban middle class of Yogyakarta. Amid the waning boundaries of traditional Islam, urban moderate Muslim clusters began to form along with the emergence of many religious programs on television and Muslim clerics. Political issues itself may not be enough to attract millions of people to Jakarta, but they are then accompanied by ethnic and religious issues. Therefore, the peaceful action that began with the issue of the election of the governor of the Special Capital Region (DKI) of Jakarta could become a national issue that could continue to grow and even expand to other issues. If examined further, the phenomenon has begun to emerge and develop since the early 1980s. The depoliticization of Islam since the 1970s has encouraged Indonesian Muslims to prioritize personal piety rather than being active in the political sphere. Since then, urban Muslim clusters far from the political frenzy have begun to form. 
From this, it seems clear that religious identity politics (Islam) is a medium of communication for middle-classes to establish networks between them. In the name of Islamic identity, which they often feel like a shared identity, there is a feeling of being together and that we are made into an attachment of a group. The rise of the Sufi urban phenomenon is no exception in Yogjakarta that cannot be separated from that spirit. Those who have felt marginalized both economically and politically have tried to rise by making the one theological sense as the media to create a shared network for the ideals of the Islamic revival.

\section{Cultural Network}

It has been mentioned above that the emergence of the middle-class urban Muslims phenomenon departs from the anxiety regarding the negative impact of modernity with all its hustle and bustle. A modern culture that offers a variety of pleasures by realizing heaven as described in the scriptures is considered by some to be very vulgar, which can threaten moral ethics. The reality of modernity above further encourages the emergence of fundamentalist movements that offer Islamic culture. In its development, this fundamentalist movement has not been able to answer this problem, especially in the middle class which is often called the urban middle-class Muslim because it is considered to be old-fashioned, traditional, and outdated, but on the other hand, they have the same attitude as the fundamentalists who reject the Western culture which is considered to damage the image of Islam. Therefore, they try to form a cultural synthesis group by offering other cultures that still feature a more modern Islamic style, not outdated, but still in the realm of sharia.

The passion to show cultural identity among the Yogyakarta middle-class Muslim can be observed in their call to return to the "pockets" as a metaphor to the mention of fundamental identity in order to block the invasion of modernity. Next, they build a wall of morality (well of virtue), based on typical behavioural values. In the "pocket culture" the view was developed that these pockets were safe areas that could form a moral and wise community. Meanwhile, outside the walls, morality is an area that is dirty, polluted, contagious, and dangerous, so it must be avoided. 
Alternatively, in other words, they embody the doctrines of "us" and "them" as a continuation of the doctrine of al-wala'/ingroup love and al-bara'/outgroup hate.

Strict effort in applying a life pattern and being rigid and exclusive can be seen in the tendency of those who place themselves differently from the surrounding community. There is a belief that the Muslim community must be built and implemented so that the glory of Islam rises. They say that the outside world is a world of ignorance that is full of bid'a (religious innovation unsanctioned by Islam) and shirk (polytheism). The emergence of distinctive Western trends and modes of culture is a threat that must be replaced with Arab-Islamic behaviour and culture as a focal point, not only in the ritual-worship realm but also in the culture of Arab society. The use of the terms ikhwain (brother, but here means Muslim brothers) and akhwāt (sister, or Muslim sisters) replaces the words friend, colleague or relative. The same applies to modesty and bodily appearance. They want to don robes, pants over the ankles, turban instead of peci, and beard symbolizing adherents of al-salaf al-sālih. At the same time, these young people prohibit smoking, watching television, or listening to music. Meanwhile, women are marked with a full black or grey dress, combined with a long hijab and eye patch. They consider the songs of the "romance" genre, either pop or jazz as Western cultures that are not Islamic.

Urban middle-class Muslim culture cannot be separated from religious, social, political, and cultural factors. Further, the new culture displayed by this group is different from the culture of Muslim groups in general, especially the fundamentalist groups. Unconsciously, the new culture they displayed also carried out cultural hegemony and finally made an offer of a new ideology. This is quite reasonable since for them the culture of exclusive fundamentalism turns out to be unable to stem the flow of highly dynamic modernity, and they are aware that the tools used to maintain the flow are by opening up and accompanied by the spirit of building a flexible Islamic labelled identity. 


\section{Conclusion}

The urban middle-class Sufism pattern in Yogyakarta places emphasis on aesthetic-symbolic values. The tendency of religious patterns of Muslim communities is, on the one hand, a form of negotiation between the values of spirituality in Islam and the forms and practices of global culture, and efforts to negotiate models of piety with economic-business motives on the other.

This form of Sufism is not institutionalized as conventional Sufism in general, that are commonly known as congregations such as qadariyya, naqshbandiyya, shattariyya, and so on. Middleclass Sufism tends to be communal since it has the same religious mission and vision. Because of the similarity of paradigm, there is a tendency towards Islamic philanthropy, political affiliation, culture, and economy. The form of communication used by middle-class Muslims in Yogyakarta is manifested in forms such as recitation, business, and other philanthropic activities such as alms, zakat, free medical treatment, and donors. They form and play their networks to frame their piety in the forms of economic, political, and cultural networks.

\section{References}

Admin. “Badan Pusat Statistik." Accessed September 13, 2019. https://www.bps.go.id/pressrelease/2018/07/16/1533/gini-ratiomaret-2018-tercatat-sebesar-0-389.html.

Alam, Anwar. "Emergence of Muslim Middle Class in PostIndependence India and Its Political Orientations." Journal of Muslim Minority Affairs 35, no. 1 (2015): 123-40. doi:10.1080/13602004.2015.1007664.

Azra, Azyumardi. "Neo-Sufisme Dan Masa Depannya." In Religius Islam. Jakarta: Paramadina, 1993.

Bayat, Asef. Life as Politics: How Ordinary People Change the Middle East. Amsterdam: Amsterdam University Press, 2010.

Bruinessen, Martin van., and Julia Day Howell. Sufism and the "Modern" in Islam. I.B. Tauris, 2013.

Budiman, Arief. Mencari Ideologi Alternatif: Polemik Agama Pascaideologi Menjelang Abad 21. Bandung: Mizan, 1994.

Djaelani, Abdul Qodir. Koreksi terhadap Ajaran Tasawuf. Jakarta: 
Gema Insani Press, 1996.

Ghasemi, Asemeh. "Muslim Iranian Women Working in Broadcast Media (IRIB): Between Motherhood and Professionalism." Women's Studies International Forum 53 (2015): 167-73. doi:10.1016/j.wsif.2015.01.003.

Haenni, Patrick. Market Islam, the Other Conservative Revolution. Paris: Seuil, 2005.

Hamka. Tasawuf Modern. Jakarta: Pustaka Panjimas, 1993.

Hefner, Robert W. "Islam, State, and Civil Society: ICMI and the Struggle for the Indonesian Middle Class." Indonesia 56 (October 1993): 1. doi:10.2307/3351197.

Hefner, RW. "Islamization and Democratization in Indonesia," 1997.

Hoffman, Valerie J. Sufism, Mystic, and Saint in Modern Egypt. Columbia: University of South Carolina Press, 1995.

Howell, Julia Day. "Sufism and the Indonesian Islamic Revival." The Journal of Asian Studies 60, no. 3 (August 2001): 701-29. doi:10.2307/2700107.

Illah, Makrifatul. "Pesan Dakwah Lagu 'Deen Assalam'; dipopulerkan group gambus Sabyan." UIN Sunan Ampel Surabaya, 2019.

Jati, Wasisto Raharjo. "Less Cash Society: Menakar Mode Konsumerisme Baru Kelas Menengah Indonesia." Jurnal Sosioteknologi 14, no. 2 (August 2015): 102-12. doi:10.5614/sostek.itbj.2015.14.2.1.

- - - "Sufisme Urban di Perkotaan: Kontruksi Keimanan Baru Kelas Menengah Muslim." Jurnal Kajian dan Pengembangan Manajemen Dakwah 05, no. 2 (2015).

- - . "Tinjauan Perspektif Intelegensia Muslim terhadap Genealogi Kelas Menengah Muslim di Indonesia." ISLAMICA: Jurnal Studi Keislaman 9, no. 1 (September 2015): 1. doi:10.15642/islamica.2014.9.1.1-29.

Johns, Anthony H. "Sufism as a Category in Indonesian Literature and History." Journal of Southeast Asian History 2, no. 2 (1961): 10-23.

Kuntowijoyo. Paradigma Islam: Interpretasi Untuk Aksi. Bandung: Mizan, 1993.

Laird, Lance D., and Wendy Cadge. "Negotiating Ambivalence: 
The Social Power of Muslim Community-Based Health Organizations in America." Political and Legal Anthropology Review 33, no. 2 (2010): 225-44. doi:10.1111/j.15552934.2010.01112.x.

Latief, Hilman. "Marketizing Piety through Charitable Work: Islamic Charities and the Islamization of Middle-Class Families in Indonesia," no. May (2017): 196-216.

Mahbubi, Akhmad, Tomohiro Uchiyama, and Katsumori Hatanaka. "Capturing Consumer Value and Clustering Customer Preferences in the Indonesian Halal Beef Market." Meat Science 156, no. April (2019): 23-32. doi:10.1016/j.meatsci.2019.05.012.

Maslow, A. H. "A Theory of Human Motivation." Psychological Review 50, no. 4 (July 1943): 370-96. doi:10.1037/h0054346.

Matt, Jarvis. Teori-teori Psikologi; Pendekatan Modern untuk Memahami Perilaku, Perasaan dan Pikiran Manusia. Bandung: Nusa Media, 2000.

Misbah, Mohammad. "Fenomena Urban Spiritualitas Solusi atas Kegersangan Spiritual Masyarakat Kota." KOMUNIKA: Jurnal Dakwah dan Komunikasi 5, no. 1 (November 2016): 135-46. doi:10.24090/komunika.v5i1.776.

Morris, Carl. "The Rise of a Muslim Middle Class in Britain: Ethnicity, Music and the Performance of Muslimness." Ethnicities, 2019, 1-21. doi:10.1177/1468796818822541.

Mujani, Wan Kamal, Wan Mohd Hirwani Wan Hussain, Noor Inayah Ya'akub, Allawati Kasri, and Ermy Azziaty Rozali. "The Political and Economic Contributions of the Muslim Middle Class in Malaysia." Advances in Natural and Applied Sciences 6, no. 3 Specl.Issue 2 (2012): 285-95.

Mustofa, Farid. "Urban Sufism: The New Spirituality of Urban Communities in Indonesia." Jurnal Filsafat 22, no. 3 (December 2012): 218-26. doi:10.22146/jf.3096.

Nasution, Harun. Falsafah dan Mistisisme dalam Islam. Jakarta: Bulan Bintang, 1973.

Nisa, Eva F. "Social Media and the Birth of an Islamic Social Movement: ODOJ (One Day One Juz) in Contemporary Indonesia." Indonesia and the Malay World 46, no. 134 (2018): 24-43. doi:10.1080/13639811.2017.1416758. 
Nizar, Muhammad Afdi. "Kelas Menengah (Middle Class) dan Implikasinya bagi Perekonomian Indonesia." Bunga Rampai Ekonomi Keuangan, no. June (2015): 173-91.

Noor, Farish A. "Popular Religiosity in Indonesia Today: The Next Step after 'Islam Kultural'?" Al-Jami'ah 53, no. 2 (2015): 283302. doi:10.14421/ajis.2015.532.283-302.

Nuh, Muhrison M. Aliran/Faham Keagamaan dan Sufisme Perkotaan. Jakarta: Departemen Agama RI, Badan Litbang dan Diklat, Puslitbang Kehidupan Keagamaan, 2009.

Nurani, Shinta. "Urban Sufism and Transformation of Islamic Culture In Millenial Society." Religia, October 2018, 158. doi:10.28918/religia.v21i2.1508.

Nurvinta, Mega. “Eksistensi Tari Sufi pada Komunitas al-Fairouz di Kota Medan." Gesture: Jurnal Seni Tari 5, no. 1 (April 2016): 85-98. doi:10.24114/senitari.v5i1.3605.

Osella, Filippo. "'A Poor Muslim Cannot Be a Good Muslim': Islam, Charitable Giving, and Market Logic in Sri Lanka." Religion and the Morality of the Market, no. May (2017): 217-39. doi:10.1017/9781316888704.011.

Permadi, K. Pengantar Ilmu Tasawuf. Jakarta: Rineka Cipta, 1997.

Ramage, Douglas E. Politics in Indonesia: Democracy, Islam and the Ideology of Tolerance. United Kingdom: Routledge, 1995.

Rofhani. "Pola Religiositas Muslim Kelas Menengah di Perkotaan." Religió: Jurnal Studi Agama-agama 3, no. 1 (March 2013).

Rosen, Lawrence. "Will the Middle Class Save the Middle East?" Contemporary Islam 5, no. 2 (2011): 185-90. doi:10.1007/s11562011-0156-9.

Rubaidi, Rubaidi. "The Role of Urban Sufism of Shalawat Muhammad Assembly on Urban Middle Class Society." Jurnal Ushuluddin 26, no. 2 (2018): 183. doi:10.24014/jush.v26i2.4895.

Rudnyckyj, Daromir. "Subjects of Debt: Financial Subjectification and Collaborative Risk in Malaysian Islamic Finance." American Anthropologist 119, no. 2 (2017): 269-83. doi:10.1111/aman.12861.

Septiyan, Dadang Dwi, and Rista Dewi Opsanti. “Dimensi Mistik Musik Sufi Kelompok Kesenian Sufi Multikultural Kota Pekalongan." Jurnal Pendidikan dan Kajian Seni 3, no. 1 (April 
2018). doi:10.30870/jpks.v3i1.4067.

Wahid, Din. "Sufism and the 'Modern' in Islam." Studia Islamika 10, no. 3 (March 2014). doi:10.15408/sdi.v10i3.628.

Yuswohady, and Kemal E. Gani. 8 Wajah Kelas Menengah. Jakarta: Gramedia, 2015.

Zamhari, Arif. "Socio-Structural Innovations in Indonesia's Urban Sufism: The Case Study of the Majelis Dzikir and Shalawat Nurul Mustafa." Journal of Indonesian Islam 7, no. 1 (2013): 11944. doi:10.15642/JIIS.2013.7.1.119-144. 